\title{
Pokémon GO: are limited physical activity benefits undermined by McFlurries consumed?
}

\author{
Mohammed Jawad doctoral candidate, Anthony A Laverty research fellow, Christopher Millett \\ professor of public health
}

Public Health Policy Evaluation Unit, School of Public Health, Imperial College London, London W6 8RP, UK

We welcome attempts from Howe and colleagues to evaluate the impact of Pokémon GO, ${ }^{1}$ which is the most downloaded smartphone app of all time. This, and nearly all other known Pokémon GO analyses, limit their investigations to the number of steps taken or other markers of physical activity. ${ }^{23}$ But what about changes in diet?

Central to players' progression through the game is accessing "gyms," where captured Pokémon can battle each other and earn rewards. These virtual gyms are placed in proximity to buildings or objects that are meant to have local cultural significance. If players place one of their Pokémons in a gym, they can receive 10 "PokeCoins" (£0.08; €0.09; \$0.10) a day to reinvest in other items to help "catch 'em all." Pokémon GO players therefore tend to congregate around gyms. But what if gyms are not in buildings of cultural significance but rather fast food restaurants?

It is perhaps unsurprising that a game promoting physical activity has succumbed to the commercial power of the fast food industry. McDonald's was the first sponsor of Pokémon $\mathrm{GO}$, and when the game was launched in Japan gyms were placed in nearly all $3000 \mathrm{McDonald's} \mathrm{restaurants.}{ }^{4}$ Alongside giving away Pokémon toys with children's meals, ${ }^{5} \mathrm{McD}$ Donald's created designated seating areas for Pokémon GO players to battle their monsters without disturbing non-playing customers.
The footfall attracted to Pokémon gyms in McDonald's restaurants is evident in Steve Easterbrook's quote: "We are enjoying what [Pokémon Go] is doing for business at the moment." ${ }^{4}$ Presumably, business is up.

With research suggesting that the physical activity benefits of Pokémon GO are short term at best, and with users being drawn to fast food restaurants to meet other gamers, we suggest that future Pokémon GO studies count the number McFlurries consumed in addition to the number of steps taken.

\section{Competing interests: None declared.}

1 Howe KB, Suharlim C, Ueda P, Howe D, Kawachi I, Rimm EB. Gotta catch 'em all! Pokémon GO and physical activity among young adults: difference in differences study. BMJ 2016;356:i6270. doi:10.1136/bmj.i6270 pmid:27965211.

2 Nigg CR, Mateo DJ, An J. Pokémon GO may increase physical activity and decrease sedentary behaviors. Am J Public Health 2017;356:37-8. doi:10.2105/AJPH.2016. 303532 pmid:27854536.

3 Althoff T, White RW, Horvitz R. Influence of Pokémon GO on physical activity: study and implications. https://arxiv.org/pdf/1610.02085v2.pdf

4 Vizard S. McDonald's on Pokémon Go. 'We are enjoying what it is doing for our business.' Marketing Week 2016 Jul 26 https://www.marketingweek.com/2016/07/26/mcdonaldson-pokemon-go-we-are-enjoying-what-it-is-doing-for-our-business/.

5 Yui M. McDonald's Japan soars as game-starved diners catch Pokémon toys. Bloomberg Technology 201619 Jul https://www.bloomberg.com/news/articles/2016-07-19/mcdonalds-japan-soars-as-game-starved-diners-catch-pokemon-toys.

Published by the BMJ Publishing Group Limited. For permission to use (where not already granted under a licence) please go to http://group.bmj.com/group/rights-licensing/ permissions 